\title{
KONSEPSI MANAJEMEN MUTU DALAM PENDIDIKAN
}

\author{
ABDUL HADI \\ Universiatas Nurul Jadid Paiton Probolinggo \\ Email: naurazufar@gmail.com
}

\begin{abstract}
:
This journal focuses on the quality of professionally managed educational institutions through integrated quality management. Educational institutions as producer services sector should pay attention to quality; quality of managerial and academic aspects. These two aspects can be achieved through the application of the concept of total quality management (TQM). TQM is a management concept that places all insan (civitass academica) of higher education institutions as individuals who have responsibility for quality in accordance with their duties and functions. TQM is an approach to doing business that seeks to maximize the competitiveness of institutions through continuous improvement of products, services, people, processes and the environment. TQM is the starting point for improving quality that will be under the jargon of "do the right thing, first time, and every time". Quality Management is part of management that aims to achieve Quality objectives through planning, monitoring, assuring and improving Quality. Involving all members of the organization brings us closer to Total Quality Management (TQM). Efficient Total Quality management system within the organization can facilitate rapidly challenges in the market. Total quality management embodies target and mission in youth education. TQM improves the quality of management and quality of work in educational institutions in general. Important points for educational improvement are scientific and technological development, social change and organizational change. The efficiency and success of education depends not only on quantity but also on quality. The indicators system the quality of education, as well as the criteria associated with the Quality indicators help schools to identify key areas of their activities their own advantages, disadvantages and opportunities.
\end{abstract}

Keywords: Management, Quality, Education

\section{PENDAHULUAN}

M utu pendidikan adalah faktor kunci untuk meningkatkan Mutu bisnis, dan karena itu memperkuat keunggulan kompetitif (Candra Wijaya, Muhammad Rifa'i, 2016). Akses ke pendidikan dan pendidikan bermutu harus dianggap sebagai kebutuhan dan hak yang saling bergantung dan tidak terpisahkan. Kurangnya pendidikan adalah penyebab utama kemiskinan. Pendidikan juga merupakan sarana yang sangat strategis dalam melestarikan sistem nilai yang berkembang dalam kehidupan (Mundiri, 2012). Pekerja intelektual menjadi alat utama dalam meningkatkan produktivitas, dan pengetahuan menjadi sumber utama. Mengakses ke persatuan Eropa untuk sistem pendidikan Indonesia berarti tantangan baru yaitu perolehan Mutu, pengelolaan, mobilitas, dan respons yang lebih baik terhadap persyaratan dan perubahan. 
Perbedaan antara sistem pendidikan modern dan tradisional terbukti dalam tujuan pendidikan yang berbeda, pendekatan pengajaran dan peran semua peserta dalam proses pendidikan (Hasan Baharun, Zamroni, 2017). Efisiensi dan Mutu adalah parameter kunci yang menentukan kepentingan sosial-ekonomi bidang pendidikan. Manajemen Mutu adalah bagian dari manajemen yang bertujuan untuk mencapai sasaran Mutu melalui perencanaan, pemantauan, meyakinkan dan meningkatkan Mutu. Dalam kondisi modern, manajemen mutu menjadi fungsi bisnis serta fungsi lainnya, yang melibatkan orang-orang dari semua profil dan dari semua organisasi.

\section{PEMBAHASAN}

\section{Konsep Manajemen}

Dalam seluruh aspek kehidupan sangatlah diperlukan manajemen, dan sampai kapanpun manajemen tak akan terlepas dari kehidupan kita. Sebuah organisasi, perusahaan maupun instansi dan lembaga lainnya membutuhkan manajemen untuk pencapaian tujuan yang diharapkan dan pastinya direncanakan.

Berbicara tentang manajemen, perlu kiranya kita mengetahui terlebih dahulu "Apa sih pengertian dari manajemen itu?"

Asal muasal kata Manajemen di ambil dari kata To Manage yang memiliki arti mengatur. Secara global Manajemen merupakan suatu ilmu dan seni untuk mengelola sumberdaya melalui sebuah kegiatan yang dikerjakan sekelompok orang atau individual agar nantinya dapat mencapai tujuan yang diinginkan organisasi atau instansi itu sendiri.

Ada 4 hal utama yang dapat di ambil dari pengertian Manajemen, yakni:

1. Suatu seni dan ilmu

Manajemen dikatakan sebagai IImu karena secara prinsip atau konsep manajemen bisa dipelajari. Seni yang ada pada manajemen merupakan suatu keunikan pada setiap manajer dalam mengatur sumberdaya melalui kepemimpinannya pada sebuah instansi/organisasi.

2. Mengelola sumber daya

Untuk menghasilkan Output yang berbobot, maka sumberdaya harus dikelola dengan cara-cara jitu dan untuk dapat menunjang hasil yang berbobot itu pula diperlukan sumberdaya yang mumpuni dalam bidang manajemen. Proses dalam mengelola menejemen ini dapat ditemukan pada unsur-unsur menejemen.

3. Pencapaian suatu tujuan

Tak dapat dipungkiri jika suatu instansi dan atau lembaga pasti memiliki tujuan, akan dibawa kemana dan dijadikan apa suatu lembaga tersebut pastinya sudah ada rancangan dan angan-angan tersendiri bagi sumberdaya yang ada didalamnya, terlebih pimpinan yang memiliki tanggung jawab penuh terhadap lembaga yang dipimpinnya. 
4. Kegiatan yang dikerjakan kelompok

Suatu kegiatan manajemen akan berhasil jika dilakukan secara bersama, karena menejemen akan timpang jika hanya berjalan serorang diri. Maka dari itu manajemen mau tidak mau harus melibatkan orang lain, dengan begitu akan timbul koordinasi antara pelaku manajemen. Nah, dengan adanya kegiatan berkelompok ini akan terjadi pembagian tugas atau job description pada para pelaku tersebut menjadi beberapa divisi.

\section{Unsur-unsur Manajemen}

Setelah kita mengetahui pengertian dan poin utama dari pengertian manajemen, maka marilah kita menelisik juga unsur-unsur manajemen. Unsurunsur manajemen merupakan suatu hal yang juga perlu kita siapkan dalam menjalankan manajemen apapun. Dalam perspektif pelanggan, organisasi perlu terlebih dahulu menentukan segmen pasar dan pelanggan yang menjadi target bagi organisasi atau badan usaha (Hasan Baharun, Zamroni, 2017). Berikut inilah yang merupakan unsur-unsur manajemen dalam suatu organisasi maupun instansi.

\section{Man (Manusia)}

Manusia berperan penting dalam suatu manajemen untuk menjalankan kegiatan manajemen. Peran Sumber daya manusia disini adalah suatu proses untuk tercapainya suatu tujuan.

\section{Money (Uang)}

Tanpa adanya uang maka suatu organisasi akan sulit untuk berjalan bahkan untuk mengembangkan suatu organisasi itu tidak akan bisa terealisasi jika tanpa uang.

\section{Methods (Metode atau cara kerja)}

Bagaimana tujuan akan dicapai sangatlah bergantung pada tekhnik yang dipakai dalam menjalankan proses manajemen, apakah menggunakan cara kerja yang baik sehingga dapat mempermudah jalannya pekerjaan hingga tercapainya tujuan akan lebih lancar.

\section{Machines (Mesin)}

Mesin atau sarana prasarana yang digunakan dapat meliputi seluruh alat atau barang berguna dalam membantu proses SDM untuk mencapai tujuan. Penggunaanya bergantung kepada manusia dalam mengoperasikannya.

\section{Materials (Bahan Baku)}

Bahan baku adalah suatu input yang harus diolah untuk menciptakan produk agar tujuan tercapai. Input ini bisa bermacam-macam sesuai dengan jenis organisasinya.

\section{Market (Pasar)}

Setelah tercipta produk akhir atau output maka hal yang dilakukan adalah pemasaran untuk tercapainya suatu tujuan, seperti misal perusahaan memasarkan produk olahannya untuk mendapatkan keuntungan.

\section{Mutu Pendidikan}


Mutu kata berasal dari kata Latin qualitas (properti, mutu, nilai, karakteristik, fitur, kemampuan). Dalam dunia yang sangat kompetitif dengan meningkatnya permintaan konsumen, mutu telah menjadi faktor kunci untuk bertahan hidup di pasar, profitabilitas dan pengembangan, tidak hanya untuk sektor dan organisasi individual, tetapi juga untuk perekonomian seluruh negara. Hanya sedikit perusahaan di Indonesia yang mengakui mutu pendidikan sebagai faktor kunci untuk meningkatkan mutu bisnis, dan oleh karena itu untuk memperkuat keunggulan kompetitif.

Mutu pendidikan adalah konsep, dinamis multi-dimensi yang tidak hanya mengacu pada model pendidikan, tetapi juga untuk misi kelembagaan dan sasarannya, serta standar spesifik dari sistem, fasilitas, program atau acara. Teori dan praktik pedagogis telah mencoba untuk menentukan mutu pendidikan. Dalam pendidikan, hanya mungkin untuk menentukan mutu dengan membandingkan hasil dengan sasaran yang diberikan, atau dengan membandingkannya dengan standar yang ditetapkan sebelumnya.

Sekolah merupakan salah satu bagian dari sebuah masyarakat(Mundiri, 2016). Setiap aktivitas manusia diidentifikasi oleh mutu produknya. Aturan yang sama berlaku untuk pendidikan. Oleh karena itu, mutu pendidikan bertanggung jawab atas mutu "produk" nya: siswa. Berbagai bentuk pendidikan hadir di tempat yang berbeda, di berbagai waktu, di bawah keadaan dan istilah yang berbeda, disengaja dan tidak disengaja, terorganisir dan tidak terorganisasi, dengan atau tanpa program. Salah satu masalah utama adalah penyatuan standar dan kriteria evaluasi mutu.

Komponen kunci dari proses evaluasi adalah pendekatan metodologis dalam menerapkan metode dan prosedur pengumpulan data yang baik, dan definisi konsep kunci dan hubungannya dengan konsep mutu. Prasyarat mendasar untuk peningkatan mutu adalah pembentukan sistem aktif evaluasi internal dan eksternal. Evaluasi internal menyiratkan peran signifikan penilaian siswa sebagai peserta aktif dalam proses evaluasi mutu dalam pendidikan. Mutu pendidikan harus dipahami sebagai aset paling penting untuk memperkuat daya saing pasar, dan dengan demikian sebagai akselerator pertumbuhan ekonomi total dan pengembangan negara Indonesia.

\section{Manajemen Mutu dalam Pendidikan}

Mutu harus secara sadar dikelola untuk memenuhi tuntutan masyarakat. Dari klaim sebelumnya kami menyimpulkan bahwa manajemen mutu adalah "bagian integral dari manajemen, yang berperan untuk mencapai sasaran mutu, yang tercermin tidak hanya dalam memberikan tetapi juga dalam meningkatkan mutu. Hal ini dicapai dengan mengelola kegiatan yang berasal dari mutu yang mapan. Kebijakan dan rencana, dan dilakukan dalam sistem mutu, menggunakan, antara lain, rencana pemantauan mutu yang tepat. Total Quality Manajement (TQM) atau manajemen mutu terpadu merupakan sistem manajemen yang dikembangkan di 
berbagai negara dalam menghadapi dunia yang cepat berubah dan penuh ketidakpastian dalam rangka menciptakan efektivitas dan kepuasan (satisfaction) (Mundiri, 2016).

Manajemen yang efisien dari suatu organisasi dicapai dengan menggunakan model yang berbeda. Salah satunya adalah sistem manajemen mutu. Dengan manajemen mutu sistem kami memahami "struktur, prosedur, proses dan sumber daya yang diperlukan lainnya yang diperlukan untuk penerapan manajemen mutu. Sebuah sistem mutu tidak dapat dipisahkan dari norma-norma dan standar internasional (standar) mutu.

Standar adalah formalisasi prinsip-prinsip dasar mutu manajemen Semakin banyak entitas (tidak hanya bisnis terkait) berusaha untuk menyesuaikan sistem Mutunya sendiri dengan persyaratan, terutama, dari standar ISO 9000. Untuk diakreditasi ISO 9001 (dari tahun 2000), auditor independen harus menyatakan bahwa organisasi memenuhi persyaratan berikut dari standar: sistem manajemen mutu, pencatatan, komitmen manajemen terhadap mutu, manajemen sumber daya, produksi, dan pengukuran, analisis dan perbaikan. Organisasi pendidikan tinggi mana pun yang ingin diakreditasi oleh sertifikat, harus melalui beberapa tahap: pengembangan sistem mutu yang mengimplementasikan persyaratan ISO 9000: 2000; pemilihan lembaga sertifikasi yang terakreditasi; pra-audit sistem mutu oleh lembaga sertifikasi; audit akhir dari sistem mutu setelah sertifikat diterbitkan; serangkaian audit yang lebih kecil setidaknya sekali setahun (Priyono, Bina, \& Priyono, 2016). Menurut beberapa pengalaman dari Uni Eropa, seluruh proses memperoleh sertifikat berlangsung antara 12 dan 18 bulan.

Sertifikat ini berlaku untuk jangka waktu tiga tahun. Jaringan Eropa untuk Jaminan Mutu di Pendidikan Tinggi (ENQA) didirikan pada tahun 2000 dengan tujuan untuk membentuk lembaga untuk jaminan mutu dalam pendidikan tinggi. Pada tahun 2004, Jaringan mengubah namanya menjadi Asosiasi Eropa untuk Jaminan Mutu di Pendidikan Tinggi (Syafaruddin, Candra Wijaya, Ahmad Syukri Sitorus, 2015).

Tujuan utamanya adalah untuk mempromosikan kerja sama Eropa di bidang evaluasi dan jaminan Mutu di antara semua peserta yang terlibat dalam proses jaminan Mutu. Agen ini didirikan di banyak negara, dan tujuan mereka diwujudkan melalui fungsi-fungsi berikut:

1. Jaminan Mutu dan peningkatan dalam pengertian tradisional. Untuk tujuan ini, lembaga harus mendorong institusi pendidikan tinggi untuk meningkatkan mutu pendidikan, terutama dengan mengevaluasinya. Proses evaluasi dibagi menjadi empat langkah, yang utama adalah penilaian diri (disediakan oleh lembaga pendidikan tinggi) dan penilaian eksternal (oleh para ahli independen). Peran lembaga adalah untuk memulai dan mengkoordinasikan proses evaluasi.

2. Melayani sebagai pusat di mana semua informasi yang tersedia mengenai implementasi dan jaminan sistem mutu dapat ditemukan. 
3. Fungsi terakhir adalah akreditasi. Berdasarkan evaluasi, lembaga menegaskan bahwa standar mutu lembaga/program memenuhi persyaratan yang diberikan.

\section{Total Manajemen Mutu Dalam Pendidikan}

Konsep Total Manajemen Mutu dalam Pendidikan, diperkenalkan oleh Profesor W. Edwards Deming pada 1950-an, dapat diterapkan ke hampir setiap organisasi hingga tingkat tertentu. Istilah ini berarti proses pergeseran fokus organisasi menuju mutu produk dan layanan yang unggul.

TQM pendekatan dalam pendidikan tidak hanya melibatkan mencapai mutu tinggi tetapi juga mempengaruhi semua segmen proses pendidikan: organisasi, manajemen, hubungan interpersonal (Mundiri, 2016), material dan sumber daya manusia, dan lain-lain. Menerapkan pendekatan yang dijelaskan di atas mutu menjadi total (integral). Pengenalan manajemen mutu total membutuhkan sejumlah perubahan dalam institusi pendidikan.

Perubahan pertama harus terjadi dalam sikap dan kegiatan manajemen, dalam organisasi dan pemantauan proses pendidikan, dalam evaluasi hasil, dalam budaya komunikasi, di atmosfer sekolah, dan terutama di bidang interpersonal hubungan. Model manajemen mutu total mencakup hal-hal berikut: perencanaan proses, manajemen proses, peningkatan berkelanjutan, keterlibatan total dan fokus pada pengguna.

Manajemen mutu total adalah teknik manajemen yang efisien yang memerlukan keterlibatan penuh semua karyawan pada semua tingkat organisasi, sehingga mewakili budaya organisasi. TQM adalah cara hidup organisasi, yang memperkenalkan peningkatan bisnis yang konstan di semua tingkat dan kegiatan, menciptakan lingkungan yang sesuai melalui kerja kolaboratif, kepercayaan dan rasa hormat. Ini mendekati proses secara sistematis, konsisten dan terorganisir dan menerapkan teknik manajemen mutu total. TQM adalah semua tentang manajemen mutu pengguna, kepemimpinan dan loyalitas manajemen, peningkatan berkelanjutan, respons yang cepat, tindakan berdasarkan fakta, partisipasi karyawan dalam budaya TQM. Jika suatu organisasi secara konstan bersedia mengarahkan usahanya menuju perbaikan bisnis, prinsip-prinsip yang disajikan di atas dapat mengarah pada keunggulan dalam mutu. Keberhasilan Manajemen Mutu Total tergantung pada delapan komponennya: etika, integritas, kepercayaan, pendidikan, kerja tim, kepemimpinan, pengakuan dan komunikasi.

\section{Indikator Kualitas dalam Pendidikan}

Sistem indikator kualitas dalam pendidikan, serta kriteria kualitas yang terkait dengan indikator, membantu sekolah untuk menunjukkan bidang-bidang penting dari kegiatan mereka sendiri - keuntungan dan kerugian mereka sendiri dan peluang pengembangan. Tim kualitas sekolah dapat berdebat tentang representasi dan pengembangan aspek indikator tertentu dan mencari metode untuk meningkatkan dan melambangkan representasi indikator dalam menentukan keadaan sekolah. 
Indikator dikelompokkan menjadi tujuh area dengan topik spesifik:

1. Kurikulum - struktur kurikulum (program/tujuan, tugas, fokus pada pengembangan tugas fungsional, fokus pada kegiatan siswa, integrasi program di dalam dan di antara area) - kursus dan program - kompetensi utama yang dikembangkan siswa di sekolah yang diberikan

2. Prestasi (dievaluasi oleh lembaga eksternal dan independen) - kualitas pencapaian dibandingkan dengan sasaran yang ditetapkan

3. Belajar dan mengajar - kerja guru - pekerjaan dan pengalaman siswa memenuhi kebutuhan siswa - memantau dan mengevaluasi kerja siswa dan guru

4. Dukungan siswa - pertumbuhan pribadi, sosial dan spiritual siswa - kemajuan dan pemantauan prestasi - dukungan dalam semua aspek pembelajaran, kemajuan, pengembangan pribadi siswa dan guru

5. Etos sekolah - kebijakan sekolah - suasana dan hubungan sekolah - tujuan spesifik masing-masing sekolah - orientasi terhadap siswa, guru dan 'kepuasan'

6. Sumber daya - sumber daya sekolah - guru, rekan profesional, kepala sekolah; pendidikan mereka, kerja tim guru, kerja sama; terbuka untuk inovasi - sumber daya material dan tempat - sumber daya manusia dan material yang efisien.

7. Manajemen, kepemimpinan dan jaminan kualitas - pendekatan untuk kepemimpinan dan manajemen.

\section{Sistem Pendidikan Tradisional dan Modern}

Sistem pendidikan diindonesia menyediakan layanan pendidikan mulai dari pendidikan prasekolah hingga pendidikan dasar, menengah, tinggi serta pendidikan orang dewasa. Pembelajaran seumur hidup sangat penting sebagai alat untuk merangsang orang dewasa, terutama yang menganggur, untuk bergabung dengan program pendidikan yang fleksibel dan mengambil bagian aktif di pasar tenaga kerja.

Dalam sistem pendidikan tradisional, tujuannya adalah perolehan informasi. Kegiatan siswa pada dasarnya terdiri dari mendengarkan dan menonton. Ceramah semacam ini melelahkan dan menghasilkan banyak fakta yang tidak perlu yang perlu dihafal siswa yang mengakibatkan siswa pada umumnya tidak puas dengan sekolah. Informasi yang dihafal dengan cara ini tidak dapat berhasil disimpan dalam memori jangka panjang.

Kurikulum yang terkait dengan mata pelajaran individu dan metode pengajaran, menekankan pengetahuan faktual dan pembelajaran pasif, sehingga tidak memungkinkan siswa untuk memperoleh keterampilan pengetahuan teknis, teknologi dan sosial yang diperlukan dalam ekonomi yang kompetitif. Satu tangan satu jumlah mata pelajaran wajib terlalu besar dan pada mata pelajaran elektif lainnya hampir tidak ada.

Karena tidak ada standar nasional, tidak ada evaluasi atau pengujian eksternal yang tidak memihak, sekolah menguji pengetahuan siswa mereka 
berdasarkan nilai mereka bukan pengetahuan mereka. Sistem Indonesia tradisional memiliki program pendidikan tiga dan empat tahun, program khusus untuk pekerja yang kurang terampil atau siswa dengan kebutuhan khusus dan sistem pendidikan ganda yang dikombinasikan dengan pekerjaan. Karena perkembangan teknologi, sebagian besar profesi yang disebutkan menjadi tidak perlu. Kurikulum terlalu terfokus pada keterampilan khusus, keahlian dan pandangan profesi tertentu.

Pendidikan kejuruan tidak cukup cepat beradaptasi dengan perubahan dalam ekonomi dan kebutuhan perusahaan kecil dan menengah. Institusi pendidikan tinggi tidak otonom, karena pendanaan dan keputusan pekerjaan sebagian besar dikendalikan oleh Dinas Pendidikan.

Program universitas tidak cukup terbuka untuk kebutuhan pasar tenaga kerja. Tidak ada standar universitas yang baik terkait pendidikan dan dampaknya. Partisipasi dalam pembelajaran seumur hidup, dalam sistem pendidikan tradisional, sangat buruk.Jumlah mereka yang hanya menyelesaikan programprogram kejuruan yang lebih pendek atau kurang menuntut (dua atau tiga tahun terakhir) sangat tinggi. Sistem pendidikan Indonesia tradisional tampaknya tidak memberikan jumlah pekerja yang cukup dengan pengetahuan dan keterampilan yang diperlukan.

Kebutuhan akan teknologi modern tidak cukup ditekankan.Teknologi baru mengubah pendidikan dengan pengembangan e-learning. Oleh karena itu, pengertian sistem pendidikan modern lebih penting daripada menghafal, dan kegiatan mengajar bervariasi dan tunduk pada kebutuhan siswa.Siswa memperoleh sejumlah kecil fakta dan generalisasi yang mereka bandingkan dengan pengalaman mereka dan berlaku dalam latihan pemecahan masalah.

Pemahaman dan penerapan fakta memungkinkan sistematisasi pengetahuan dan daya tahannya, karena disimpan dalam memori jangka panjang. Keterampilan mengajar berubah dan secara bertahap berubah menjadi seni mengajar anak-anak untuk mengajar diri mereka sendiri. Oleh karena itu, hasil utama dari belajar adalah belajar cara belajar.

Dalam masa perubahan sosial dan ekonomi yang cepat, yang menghasilkan perubahan di pasar, sangat penting untuk mengkoordinasikan dan menghubungkan pendidikan pra-dasar, primer, sekunder dan tinggi, serta pendidikan dan pelatihan orang dewasa. Belajar sambil bekerja menjadi bentuk pengembangan profesional yang sangat penting, dan inovasi sering interdisipliner dan datang sebagai hasil kerja tim.

Menghubungkan pendidikan ke dunia kerja adalah faktor kunci dalam mengubah sistem pendidikan di Indonesia dan membuatnya mampu memenuhi kebutuhan pasar dan masyarakat, dan dengan melakukannya meningkatkan kemungkinan pekerjaan. Pendidikan tinggi dikaitkan dengan segmen lain dari 
sistem pendidikan. Output pendidikan menengah adalah input untuk pendidikan tinggi, membuat kualitasnya tergantung pada kualitas pendidikan menengah.

Pendidikan tinggi, khususnya universitas harus, oleh karena itu, berpartisipasi dalam membangun sistem evaluasi eksternal dari pencapaian siswa, dalam produksi program sekolah menengah dan buku pelajaran, dan dalam memastikan kualitas pendidikan para guru.Institusi pendidikan tinggi adalah tempat pendidikan permanen karyawan yang berpendidikan tinggi, yaitu pendidikan formal dan informal mereka lebih lanjut adalah bagian dari sistem pendidikan seumur hidup. Institusi pendidikan tinggi mengatur pelatihan lebih lanjut dalam kerjasama dengan layanan pendidikan perusahaan dan organisasi lain dan dengan asosiasi profesional.

Dengan kemajuan pengetahuan, kemungkinan pendidikan menjadi semakin bervariasi.Pendanaan negara yang terbatas mendorong peningkatan jumlah lembaga untuk mencari berbagai model pendanaan, terutama dari sumber-sumber swasta. Ada semakin banyak fasilitas pendidikan tinggi swasta di pasar. Mereka hanya menarik siswa kaya, sedangkan mereka yang tidak bisa membayar beberapa ribu kunas untuk biaya kuliah pergi ke universitas negeri. Kecuali program kelembagaan juga internet menjadi media pendidikan yang paling menonjol. Internet adalah alat untuk tidak belajar secara skolastik (Boham \& Rondonuwu, 2017). Dengan menerapkan postulat TQM untuk pendidikan, kami menyatakan bahwa pendidikan bukanlah kegiatan sosial, tetapi aktivitas pasar yang kompetitif serta yang lain.

\section{Konsepsi Manajemen Mutu dalam Pendidikan}

Konsep manajemen mutu menjadi instrumental dalam membawa perkembangan ekonomi sebuah negara, pendidikan merupakan salah satu layanan dasar yang ditawarkan oleh pemerintah dan stakeholder untuk masyarakat (Mundiri, 2017). Namun, ekspansi kuantitatif belaka tidak akan menghasilkan hasil yang diinginkan kecuali standar kualitas tertentu dipertahankan, itu penting bahwa kebijakan mengalihkan fokus mereka dari peningkatan pendaftaran ke kualitas peningkatan di semua bidang mulai dari membuat fasilitas sekolah tersedia untuk siswa, mengembangkan keterampilan belajar mereka yang tidak hanya terbatas pada kurikulum pengetahuan, dan memulai praktik mengajar yang efisien.

Konsep kualitas dalam bidang pendidikan bukanlah hal baru; oleh karena itu, penting untuk memahami bagaimana Perdebatan kualitas telah berkembang selama bertahun-tahun dan bagaimana hal itu telah dikaitkan dengan penyediaan pendidikan. Dikatakan bahwa konsep kualitas dalam pendidikan bersifat multifaset karena tidak memiliki definisi khusus, sarjana yang berbeda telah ditafsirkan konsepnya berbeda. Perbedaannya tidak hanya terletak pada cara konsep ini didefinisikan, tetapi juga tercermin dalam cara di mana kualitas diukur.

Meskipun, di seluruh dunia, inisiatif penelitian telah dilakukan untuk mengidentifikasi indikator kualitas, mengukur hasil pendidikan, dalam konteks 
Negara Indonesia, masih sedikit bukti yang tersedia, khususnya dalam kasus pendidikan menengah. Dalam menggunakan Konsep Total Quality Managament, lembaga pendidikan berhasil mendistribusikan akumulasi pengetahuan mereka dan meningkatkan efisiensi mereka.

Total Quality Managament membantu mencapai tujuan dan tugas pendidikan generasi muda. Konsep TQM tidak hanya meningkatkan kualitas manajemen tetapi juga seluruh institusi pendidikan. Salah satu kemungkinan penggunaan manajemen kualitas total dalam pendidikan di Negara Indonesia adalah pendekatan berdasarkan Standar untuk manajemen mutu dalam pendidikan, Standar untuk manajemen mutu dalam pendidikan, menunjukkan validitasnya dan dapat direkomendasikan sebagai model yang memberikan kualitas pendidikan kepada pengguna institusi yang menerapkannya. Penerapannya yang luas di Negara Indonesia, serta di luar negeri, di masa depan, menegaskan bahwa pengantarnya dalam sistem pendidikan terpadu dibenarkan.

\section{PENUTUP/SIMPULAN}

Kualitas istilah, yang meliputi aspek ekonomi, sosial, kognitif dan budaya pendidikan, dianggap sebagai fitur integral dari proses pendidikan dan hasilnya. Dengan memberikan layanan pendidikan berkualitas tinggi, lembaga pendidikan memainkan peran penting dalam pengembangan ekonomi nasional, masyarakat secara keseluruhan dan anggota individu. Total Quality hanya dapat dicapai dengan mendirikan organisasi inovatif, yang fleksibel, yang dapat menyesuaikan dengan cepat terhadap perubahan lingkungannya dan mampu belajar. Untuk meningkatkan kualitas pendidikan, sebuah faktor penting dari pembangunan ekonomi dan sosial, sangat penting untuk mengurangi jumlah besar pengetahuan yang seharusnya dikuasai oleh para siswa, memusatkan perhatian mereka pada sistem pengetahuan dasar, pada kreativitas, pemecahan masalah dan belajar sepanjang hayat.

\section{DAFTAR PUSTAKA}

Boham, A., \& Rondonuwu, S. A. (2017). e-journal “Acta Diurna” Volume VI. No. 2. Tahun 2017, VI(2).

Wijaya, Candra, Muhammad Rifa'i, (2016). Dasar-Dasar Manajemen. (M. S. Syarbaini Saleh, Ed.). PERDANA PUBLISHING Kelompok Penerbit Perdana Mulya Sarana (ANGGOTA IKAPI No. 022/SUT/11) Jl. Sosro No. 16-A Medan 20224 Telp. 061-77151020, 7347756 Faks. 061-7347756 E-mail: perdanapublishing@gmail.com Contact person: 08126516306.

Baharun, Hasan, Zamroni, (2017). Manajemen mutu pendidikan.

Mundiri, A. (2012). Pendidikan Teknohumanistik Berbasis Core Ethical Values. AtTajdid: Jurnal IImu Tarbiyah, 1(1), 37-47. 
Mundiri, A. (2016). Strategi Lembaga Pendidikan Islam dalam Membangun Branding Image. Pedagogik, 3(2), 58-72.

Mundiri, A. (2017). Organizational Culture Base On Total Quality Management In Islamic Educational Institution. ADRI International Journal Of Islamic Studies and Social Sciences, 1(1), 1-11.

Priyono, P., Bina, U., \& Priyono, P. (2016). Buku pengantar manajemen, (July).

Syafaruddin, Candra Wijaya, Ahmad Syukri Sitorus, (2015). Peningkatan Konstribusi Manajemen Pendidikan dalam Pengembangan Sumber Daya Manusia Berkualitas untuk Membangun Masyarakat Ekonomi ASEAN. (D. Prof. Dr. Syafaruddin, M.Pd, Ed.). 